\title{
The Impact of a Mosque-Based Islamic Education to Young British Muslim Professionals
}

\author{
Nader Al-Refai \\ Yarmouk University, Irbid, Jordan \\ https://orcid.org/0000-0003-2506-5778
}

\begin{abstract}
This article explores the contribution of the mosque towards the social, mental, and spiritual development of young British Muslims (YBMs) through their educational system. This qualitative inquiry investigates this social phenomenon in its 'real' context from the perspective of a purposive sample of five young British Muslims who experienced 'mosque education' throughout their childhood, and now as young adults are highly qualified professionals in different sectors. The data were collected through five deep semi-structured interviews; the analysis of the data followed a qualitative thematic analysis. Key findings were that mosque education has helped these YBM to develop their social, mental and spiritual skills in British society, participants recognized the contribution of this education towards their social and mental development to a greater degree than if it were merely their spiritual development, participants observed that the 'mosque education' has great potential, and should be expanded. Participants identified several limitations of mosque education that were hindering its role and presented challenges to teachers, imams, curriculum, pedagogy, and integration efforts in an age of Islamophobia.
\end{abstract}

Keywords: Mental development; Mosque education; Social development; Spiritual development; Young British Muslims

\section{Introduction}

In the Islamic understanding, education is viewed as a fundamental obligation of any observant Muslim. Prophet Mohammad says: "Seeking knowledge is an obligation upon every individual Muslim, male and female." (Ibn Majah, 2007 No: 224). There are three terms in the Arabic lexicon used to mean education, each differing in connotation but embodying the various dimensions of the educational process as perceived by Islamic thought. The first term is Tarbiyah, which implies a state of spiritual and ethical nurturing following the will of the Lord. According to Halstead (2004), this term refers to the development of individual potential and to the process of nurturing and guiding the child to a state of completeness or maturity (Al-Hashimy, 2006). In the Qur' anic context, Tarbiyah has two meanings: "bringing up" (Qur'an 26:18) and "growth" (Qur'an 22: 5). The second term is $T a^{\prime}$ dieeb, which refers to the process of character development and learning, as a 
sound basis for moral and social behaviour within the community and society at large. This includes the process of understanding and accepting the most fundamental social principles, such as justice and citizenship (Al-Hashimy, 2006; Al-Refai \& Bagley, 2008; Halstead, 2004). The third term is Ta'leem, which refers to the imparting and receiving of knowledge, usually through training, instruction, or another form of teaching including Arabic language skills, and Qur'anic learning and recitation (Al-Hashimy, 2006; Halstead, 2004).

Islamic Education (IE) is meant to be a comprehensive concept that covers the complete scope of spiritual, social, and mental development of humans. In the same vein, Ikhwan and Jaelani (2014) argued that IE entails building up the complete character. As such, it should be oriented to the construction and renewal of the intellect, taking into account science, creativity, and the progress and morality of the human personality and society in order to build a satisfying quality of life. The Islamic view of education focuses therefore on wholeness that covers all aspects of an individual's life and prepares individuals not only for this world but also for the Hereafter.

Islam considers seeking knowledge as a way to please Allah the Creator, a concept which puts the onus on the Muslim to fulfil certain personal responsibilities, such as seeking education for oneself and one's children, in ways which will ensure their spiritual enrichment, teach them their duties as citizens, and prepare them to live and work in ways which serve the community. Islam views education not only as a means to learn, but also as a tool to develop the society by preparing its individuals to become excellent citizens, taking part in constructing and developing society while living according to Muslim values (Ikhwan \& Jaelani, 2014). Indeed, this implicit role of Islamic education is as important as its more formal role (Tamuriet al, 2012).

At the heart of the Islamic educational system of the Muslim minority in Britain are the traditional social institutions of the family (Al-Usrah), the mosque (AlMasjid) and the school (Al-Madrasa), elements that bear great importance in the Islamic perception of education (Abdel-Hady, 2010). These three different institutions contribute significantly to the process of teaching IE to YBM and complement each other to a great extent. However, there are a few differences in the way they interact with children and in the formality of the type of education they provide. It is believed that these institutions need further independent research to highlight the main challenges facing their existence.

The mosque (Al-Masjid) is considered one of the most important educational institutions in the life of the Muslim community. It is the first institution from which the rays of science and enlightenment were emitted in the early days of Islam. The nature and history of Islamic upbringing and education have inseparable ties to the mosque (Zaimeche, 2002). It has a very important role and duty since the dawn of the Islamic era (Triayudha et al, 2019). According to Tamuri (2012), the mosque was the first and for most Muslims, most important institution in teaching Islamic education since the days of Islam's foundation. It has been and remains the central place for all kinds of different activities of Muslim communities. For example, an important aspect of mosque activity involves the 
social side of the prophetic life. The Prophet's mosque contained a special room called Suffah, from where support was distributed to needy people (Triayudha et al, 2019). According to Spahic (2009), the establishment of the mosque represented a nucleus for the believer's existence, an epitome of the endless struggle between good and evil on the earth. Therefore, during the significant period of the Prophet's era, the mosque was seen as the ultimate centre for the Muslim Ummah (nation) where various activities were conducted (Tamuri et al, 2012).

The Prophet was careful to make effective use of this institution as a place for holding dialogue and spreading his educational message to the Muslim community in Madinah (Al-Ghazali, 2018). The mosque was profoundly important to Prophet Mohammad, and it was the first thing he founded after migrating to Madinah to escape the persecution he and his followers were suffering in Makkah (Triayudha et al, 2019). The mosque then became the first educational institution for the Muslim community in Madinah. According to Mortada (2003), in the early periods of the Islamic State, the mosque was the place where teaching and learning religion-related subjects were conducted by 'Ulama. The role of the mosque established by the Prophet continues until the present time. His companions and followers utilized this educational institution in the preparation of a generation that would stand out through the ages, for the mosque produced succeeding generations which served as a beacon of science and guidance around the globe (Al-Ghazali, 2018).

\section{The Contribution of the Mosque}

Throughout the different phases of Islam, the mosque has contributed to forming the Muslim character. According to Zaman and Memon (2016), the comprehensive nature of religious education provided in mosques, covering all aspects of life both in this world and the hereafter, offered to the whole range of age groups and genders alike, has an important impact on the educational process for individuals and the community as a whole. It exemplifies the principle of universality and continuity of education in both Muslim majority cultures, and in Muslim communities of the diaspora. The Masjid has contributed to the development of the Islamic Education concept in different parts of the world take as examples the mosque's impact on teaching Islamic education in Indonesia, or to Malaysian students (Triayudha et al, 2019; Tamuri et al, 2012).

Today, we are dealing with the term "Mosque Education" to encompass all the teaching within the Masjid such as unofficial religious education, Qur'anic schools, hifiz, and tajwid classes, and further to include lessons on Sirah and Islamic mannerisms and behavior (Zözeri et al, 2017). The mosque carries out a variety of educational functions, including instilling the doctrine of Tawhid, educating young people to cherish their religion, developing the inclination to self-sacrifice, building a system of moral and social values, addressing misguided negative behaviours and alerting Muslims to the danger of cultural invasion, in addition to supporting school education through various programs. Clearly, the mosque performs a wide variety of educational functions. It is here that young Muslims learn the concept of Tawhid and to cherish their religion. Additionally, the mosque teaches them the inclination to self-sacrifice and a solid system of moral and social values, while addressing misguided negative behaviours and alerting Muslims to 
the danger of cultural invasion and supporting school education through various programs (Rasdi, 2014). The role of the mosque as an effective and influential educational medium in building the new generation can be attributed to several factors, the most important of which is the link between the mosque, and faith and spirituality. It is a place imbued with an atmosphere of worship and performance of rituals, thus making it a focused environment possessed of an air of everpresent energy, a place of refuge, and righteousness (Rasdi, 2014).

In addition, mosque learners feel a sense of security and peace of mind in the richly carpeted interior of the mosque in which young people, learn, relax, and pray. All of these are derived from being in the privacy of a place which is warm, welcoming, and both physically and ritually clean (Rasdi, 2014). This appears to have a profound effect on the learner's frame of mind and helps to create a comfortable learning environment. A further factor is that the prestige of the mosque and its distinguished status affects the attitude of the students who attend regularly, and this can create in them a serious desire to commit to the educational process, and work to achieve their envisaged educational goals. The fact that students come to the mosque to learn decreases the problems of motivation, as it is not compulsory, in contrast to school learning. This may have a great impact on the response of learners and helps them to reap the benefits (Abu Daf, 2007).

\section{Mosques in the UK}

In 1961, only seven mosques were registered in the UK. Two years later, this number had risen to thirteen. In subsequent years, the number jumped to at least 1,000 (with many more being unregistered) according to Naqshbandi (2017). This reflects not only the increase in the number of Muslims in the UK but also the greater spiritual awareness and commitment of the new generation of Muslims. According to Alsaawi (2017), there are now more than 1,834 mosques. Many of the new purpose-built mosques in the UK have been designed in the likeness of the Islamic architectural styles seen in mosques in the Muslim world, unlike most of the Muslim places of worship which were converted from terraced houses, commercial plants, and former churches (Naqshbandi, 2017). In Islam, the person who dedicates their wealth to the building of a mosque may be rewarded with special favour on the day of final reckoning.

The growing number of mosques in Britain is an indication of how important this institution is to the Muslim community. According to Triayudha et al. (2019), the role of the mosque in the West today is as relevant as it was in the earliest days of Islam, when the first masjid performed the function of a centre for the Muslim Ummah where they could practice all of the activities of worship, in addition to receiving education, welfare, and even shelter. In other words, the mosque is both a community centre and a place where one can participate in several social and educational activities under one roof (Tamuri et al, 2012). To limit the view of the mosque as being 'merely' a place of worship is to severely underestimate the role of this institution, as well as the great part it has to play in creating a new generation of good citizens (Tamuri et al, 2012).

In the UK, Islamic religious leaders have resisted the pressure to "assimilate", avoiding pressures to imitate the Christian model, which largely marginalises the 
place of worship to a single day's activity. Larger mosques in Britain are open daily from the time of the dawn prayer until late in the evening, and contain facilities for wudu (ritual washing), places for food preparation and consumption, meeting and teaching rooms, and large and small prayer halls for different groups. During the holy month of Ramadan, larger mosques will remain open for 24 hours, with continuous periods of Qur'anic reading, worship, and the shared meal following the breaking of the fast. The mosque is a warm, welcoming place with shoes left at the door, and the feet of the visitor are welcomed by the rich softness of the carpets on which the believers prostrate in prayer. The entire ethos of the mosque trembles with prayer, surrender and devotion to Allah. It is a place not only of worship, but of sociability, conversation, warm greetings, and hours of study by the young and old.

In the Islamic world over the centuries, the relation between mosques and schools has gone through several distinct stages. The mosque was the main media of teaching Islamic Education to Muslims before the introduction of schools by the state (Tamuri et al, 2012). After the establishment of state schools, the mosque lost part of its traditional educational role, and was reduced to being largely a centre for rituals and worship in the form of the five daily prayers, the congregational prayers on Fridays and the two annual Eid festivals (Rasdi, 2014; Tamuri et al, 2012). There was for a long period a decrease in the role of the mosque to the extent that teachers, in Malaysia for example, made it clear that they preferred to teach Islamic Education in school classrooms rather than in mosques (Tamuri et al, 2012).

However, with the resurgence of Islam in Britain, teaching and learning are now taking place in the many UK mosques, including "Qur' an schools", "Madrasah" or "Masjid Madrasah" (Zözeri et al., 2017). According to Tamuri et al., (2012), many mosques today are well equipped with teaching and learning and ICT resources e.g. computers, big screens, purpose-built teaching halls, and classrooms. The only problem is the lack of coordination between the mosque and the schools since competing groups make demands on space and facilities in the Masjid.

\section{The Impact of the Mosque on Children}

The available research on today's impact of mosque education on children reveals two main standpoints: with and against (Zözeri et al., 2017). Critics argue that attending the mosque may have a negative impact on students' reading and writing skills, their civic values, and social cohesion within the society, but these criticisms are often framed in Islamophobic terms by those who wish Muslims in Europe to keep their religious values, dress, and personal modesty "under the radar" (Zözeri et al., 2017). Rosowsky (2013) argued that students who read and recite holy texts and scripture (i.e. reciting and memorising Qur'an) without comprehending its meaning are subjected to further negative impact related to their school education, mainly in terms of reading and comprehension skills, which might be a disadvantage for bilingual migrant students. The tenor of Rosowsky's negative and, in our opinion, biased thinking, may be judged from the summary of his article. Authors also warned about the irregularities taking places such as child abuse and maltreatment of the children attending mosques for learning. There was a concern in the discussed literature about corporal 
punishment during lesson time in the mosque (Cherti \& Bradley, 2011; RajabiArdeshiri, 2011).

Criticism has also been directed at pedagogical training of mosque teachers since some of the volunteer teachers have not been trained or inducted into Western, secular forms of psychological instruction (Khan et al, 2005; Sieckelink et al., 2012). In a study by Cherti and Bradley (2011) for instance, they reported that $40 \%$ of their sample was taught by imams who were not supporting children "in understanding their dual British-Muslim identity". Lewis (2002) argued that among their mosque sample, there were teachers who had graduated in religious education abroad who were allegedly unable to relate religious knowledge content to the social and cultural demands of the life of the new generation (Zözeri et al., 2017). These are biased views that appear tantamount to declaring that Islam and its teachers are no longer relevant in the modern age. The believing Muslim certainly holds that the Qur'anic revelation and the Sunnah (the life and teaching of Prophet Muhammad) remain highly relevant in today's world and are indeed of timeless relevance. Modern pedagogy is charged with the task of transmitting these ideas, knowledge and values to a new generation. The same argument counters critics who have argued that mosque education indoctrinates learners while promoting acceptance of authority and inhibiting a learner's autonomy (Halder, 2013; Sahin, 2013). The counter argument is that Qur'anic knowledge is a prelude to exegesis, a critical understanding of Islamic theology and the moral rules (Sharia) which are derived from this understanding. Those who argue that the type of education delivered in the mosque is 'not compatible with citizenship education, failing to develop critical thinking and respect for opposing views' (e.g. Cherti \& Bradley, 2011; Schuitema et al., 2005; Ten Dam \& Volman, 2004) do so on the basis of flimsy evidence or biased perceptions, without understanding the role of the Masjid and its meaning in the lives of Muslim citizens. In this regard, Adam-Bagley and Al-Refai (2019) have tried to offer a more balanced view of the evidence. Bhuiyan (2010) pointed to some studies which argue (or allege) that mosque education promotes traditional gender roles and 'sexist attitudes' through offering teaching on the modesty of dress and guidelines on the behaviour which Islam requires in gender relationships. These biased views fail to understand Qur' anic teaching of the absolute equality of males and females (e.g. Husain, 2018), and the central principle that modesty should inform all human social institutions (Adam-Bagley \& Abubaker, 2019). These ideas are based on the Islamic principle which reflects the Hadith of Prophet Muhammad: "Every faith has its own identity, and ours is modesty" (An-Nawawi, 2014).

On the other hand, research in the field of mosque education has highlighted the positive impact of this type of education upon the learner's self-confidence, school performance, and social intelligence (Zözeri et al., 2017). Ahmed (2012) and Meer (2009) pointed out that mosque education has a positive impact on improving students' sense of belonging to their country of settlement, increasing their confidence, and developing students' moral resolve. Gent (2011); Berglund and Gent (2019) have observed that Qur'anic learning helped them transfer some study skills such as memorisation into their formal school education. Further, Maylor et al., (2010) confirmed that attending mosque education increases enthusiasm for attending state schools. Pels (2014) noted that in some mosques, 
instructors have managed to replace previous authoritarian teaching styles with reformed pedagogical practices - 'child friendly' instruction with a role for new sorts of participatory learning activities, such as discussions, singing, and learning with an element of play. Furthermore, Moutselos (2019) reported that mosques in the UK and Germany contribute positively to political awareness since people attending these mosques are now taking part in democratic elections. The results of this and other studies counter critics who allege that mosques are places for self, social and civic isolation, rather than for participation in the democratic life of Western societies (Moutselos, 2019).

\section{The Research Rationale and Importance}

This issue must receive some focus in the form of serious research, firstly due to the aforementioned rise in the number of mosques and students attending their educational programs in the West; and secondly, due to the fact that there is relatively little research in this field, as noted by Barger (2014), Moore (2012), Pels (2014) and Zözeri et al., (2017). Thirdly, mosques have great potential to impact the religious education of YBMs and consequently, they can play a vital role in achieving social security and promoting positive integration in the multi-faith and multicultural society. Fourthly, exploring areas of concern within the mosque education may help policymakers to provide better help to activate the role of the mosque in the wider society. For instance, there is a wide spectrum of Islamic religious sects preaching their classical understanding of Islamic Education to YBMs in a very diverse society which might impact their views of modern society. Finally, among the second and third generation of YBMs, there is a growing number of professionals who survived the classical traditional education system and managed to give good examples and be role models for their peers and the generations to come. Studying the views and perceptions of this group will have many implications for the British Muslim education system.

\section{The Research Problem and Questions}

The mosque education experience in the British context is rich and different from other European countries, due partly to the nature of British society and partly to the nature of the British Muslim minority. Mosque education in Britain is diverse and is influenced by the diversity of the ethnic origins of the various Muslim groups. The Muslim minorities running these institutions reflect different cultures, traditions, languages, and religious groupings within Islam. This diversity came with the first generation of Muslims to the UK and became institutionalized in the later stages of multicultural integration in Britain (Modood, 2013). English mosques tend to reflect not only local Muslim communities but also the linguistic and cultural interests of the communities they serve. Thus, in the same city, there may be mosques that serve a Pakistani-origin community, parallel to mosques that serve populations of Middle Eastern origin. In one, the khutba (Friday sermon) is delivered in Urdu (perhaps with a summary English translation), while in another the sermon is delivered in Arabic. Mosques where Arabic is the predominant language have the benefit of being able to directly access the Arabic text of the Qur'an. In an Urdu-speaking mosque, adults and children have to learn Arabic to fully understand the message and meaning of the Qur'an. 
Today, the second and third generation of British Muslims may be evolving a different Islamic identity than that of their immigrant parents and grandparents. There is certainly a need to know the extent to which the mosque is still playing an important role in providing the Islamic education of Young British Muslims (YBMs). Therefore, the current research tries to explore the experience of a selected sample of YBMs on the contribution of these institutions to their Islamic education, and later to their professional life and social identity. This research may, therefore, identify some shortcomings of mosque education from the standpoints of the participating YBMs. Thus, the current research aims to answer the following research question:

RQ: To what extent has mosque education contributed to the social, mental, and spiritual development of a selected group of YBMs from their perspectives?

\section{Methodology}

The present study is qualitative, as it deals with the social phenomenon in its real context through investigating the perspectives of a selected sample of the second and third generation of Young British Muslims on the contribution of their mosques to their social, mental, and spiritual development.

By Young British Muslims, I mean the children of the first generation of British Muslims who migrated to the UK after the Second World War. These YBMs were born, raised and educated in the UK, attending both the official British educational system and the supplementary traditional system (including mosques and madrasas). Thus, they managed to accomplish the requirements of professional training and succeeded in finding employment in either the public or private sector and started to establish their independent families.

\section{Designing Interview Schedules}

The design of the interview questions was informed by two factors; firstly, the researcher's long experience in the field (nearly 14 years as a researcher and Islamic Education teacher in different institutions in the Muslim community); and secondly, the literature review conducted prior to designing the research tool. An external audit was performed by an expert in the British field. The audit included validating the interview schedule, the collected data and the initial data analysis findings. All the feedback was collected and addressed in different phases of the research.

\section{Data Collection}

The evidence for this research was gathered through five deep semi-structured interviews conducted with young British Muslim professionals (one medical doctor, two software engineers, one imam, and one qualified teacher). Those five individuals were selected purposely as they make good 'Key informants' for the studied phenomenon since they attended 'mosque education' in their early childhood and completed their traditional memorisation (Hifiz) of the entire Holy Qur'an by heart. This is a highly selective sample of a group of ideal youth, who are manifestly successful in achieving the moral, spiritual and social goals set by Islam. The results show the ideal working of mosque education and its desired outcomes. It is wise to bear in mind that in some areas and for many individuals, 
outcomes may not be so ideal. This particular method has been chosen in order to exemplify 'ideal cases', whose multifaceted accounts elaborate on the strengths and challenges of mosque education in Britain today. The aims of this kind of methodology are well-described by Crowe et al. (2011).

\section{Data Analysis}

The fieldwork provided sufficient data with which to understand the contribution of the mosque education on YBM's Islamic education. The interviews were used to elaborate and explore outcomes and opinions of a group of young Muslims selected because of their manifest success at combining Islamic and British identities in a multicultural society where being a Muslim is subjected to different kinds of pressures, including the negative pressures of Islamophobia.

The notes and the data collected from the interviews were subjected to extensive and deep analysis following three phases, as follows: The first phase of the analysis started with a deep reading of the transcribed material and the notes taken during the interviews. The first reading aimed at making codes and categorizing certain points found throughout the scripts. Second and third deep guided readings were conducted and data were represented in tables for a better understanding. The first phase revealed different codes and categories. The analysis benefited from the steps suggested by Tesch (2013) but was heavily based on the thematic analysis model outlined by Attride-Stirling (2001). In the second phase of the analysis, a more organised effort was made to establish relations between themes that had emerged during phase one. According to AttrideStirling's model (2001), this is known as the process of 'organising themes'. The last phase of analysis was geared towards identifying a systematic approach to presenting the main findings in a narrative style. This is called the 'global themes' according to Attride-Stirling's model (2001). These are 1) ME's impact on social life; 2) ME's contribution to mental development; 3) ME's contribution to spiritual development.

\section{Research Limitations}

The current research was confined in scope with regard to some issues. Since the researcher no longer resides in the UK, it was challenging to pinpoint more than five successful professionals who meet the selection criteria for this research. Therefore, the current research is limited to the views and perceptions of five participants. Additionally, interviews were conducted over the phone and using different means of communication i.e. the WhatsApp application, Skype, and emails. Finally, since the sample is small, there is no intention to generalise the findings to fit a wider community.

\section{Findings and Discussion}

These findings were informed by the main research questions, which cover three main areas: social development, mental development, and spiritual development. Within these main areas, the following topics were explored.

\section{Social Development}

Research findings show that mosque education can play a very important role in the social life of YBMs in the UK. Those interviewed described the mosque as $a$ 
social hub and a venue for daily social activities. This is similar to the role of the mosque in the early stages of Islam during the time of the Prophet (Al-Ghazali, 2018; Triayudha et al., 2019). For YBMs and the whole of the Muslim minority living in the West, the mosque is potentially a place to carry out many social activities e.g. marital connections, invitations, professional gatherings, offering advice, and healthcare facilities (Tamuri et al., 2012). It helps the youth to enjoy out-of-school time through regular social activities such as sports and various capacity-building workshops. Ideally, it can be a platform for the community to receive support for mental health and other types of support. One participant said:

Firstly, if we look at the Seerah of the Prophet (saw), we learn that the masjid was a social hub for the community... for young adults, the masjid could be a place where marital issues, aqiqahs, professional connections can be made... and this can be further helped through regular social activities, for example, football tournaments, weekly football sessions, ...table tennis, indoor football facilities, wrestling area, archery workshops, calligraphy courses... I feel an added dimension would be community activism and social work. With the rise of mental health problems in the UK and amongst the Muslim community, ensuring that families are well-supported and receive the relevant counselling is also critical. (Saj)

Mosque Education is an important agent of change for the YBMs and it can contribute towards preparing them to live in a British society through the provision of educational programs to limit the widely-spread culture of irresponsibility among the new generations of YBMs (Cholil, 2016). One participant said: "... it helps them [students] understand what it means to be British, what it means to be Muslim, and how we [YBMs] should engage with the people of this country as British Muslims" (Ham). One study participant, who is an Imam, added: "we [Imams] can organize outreach programs to curtail a culture of irresponsibility, particularly amongst millennials and we [Imams] can develop partnerships with local youth groups" (Zai).

Mosque education has contributed to the building of YBM identities. Participants demonstrated that attending different activities provided by the mosque was the main factor in shaping their identities in childhood (Zaman \& Memon, 2016). Further, they believed that it is the mission and duty of the mosque in the community to inform the building of a strong Muslim identity and to equip it with the needed skills to excel in the multifaith society. One study participant said:

...[it helped me to] develop a young Muslim identity which I was very confident with as a young boy (under 8 years)... being connected with a masjid or multiple masjids, is critical in building a strong Muslim identity for YBMs and this can be further helped through regular social activities ..., the masjid education should be managed in a way whereby it creates individuals with a strong confident Muslim identity. This can be through public speaking exercises, regular diversity and tolerance workshops, courses, and interfaith activities. (Saj)

Mosque education promotes tolerance through a variety of social activities in place (Tamuri et al., 2012). Encouraging tolerance with the wider society and 
establishing good relations with the non-Muslim community is one of the main aims for each mosque committee (Rasdi, 2014). Participants have addressed this issue in many ways and highlighted the role of the mosque in reaching out to the non-Muslim community through its activities to promote tolerance in society. Yet, participants emphasized that they expect more of these efforts from the mosque committees. One participant said:

... I believe masjid communities and Muslims, in general, should establish strong positive relationships with their fellow neighbours and non-Muslims. This can be done through regular open days, feed the homeless events, blood donation drives, working with local charities, hospitals, hospices, and facilitating for Dawah work. (Saj)

Similarly, in the context of teaching and learning happening inside the mosque, participants showed their interest in seeing more attention being given to promoting authentic content about non-Muslims as a highly beneficial practice. One participant expressed the value he gave to "respecting and teaching authentically about non-Muslims. Without bigotry, without hatred, without simplistic explanations or oversimplifications" (Ham). The taught curriculum in the mosque education system should contain aspects related to empowering YBMs to live in the society even if the practices of that society contradicted their basic beliefs: they still had to understand the haram (forbidden to Muslims) practices of the wider society. Participants believe also that this is not going to be easy for mosque education. Also, the informants felt, they had to face the challenges and limitations posed within their community. For example, religious sectarianism inside the Muslim community and its negative impact on the mosque committees were seen as playing a role in the decline of the mosque in issues of importance for the new generation. A participant said:

For example, if a child wants to know about homosexuality in Islam, they need to be answered. They should know what the Islamic stance is, what the average British non-Muslim's stance is, and why they have their stance. They should be told what the difference is between Muslims and non-Muslims and why some things seem to be okay for non-Muslims but are not acceptable for Muslims... it is impossible to prepare YBMs to face the challenges they will inevitably face if the mosque itself does not understand those challenges...Sectarianism is a huge challenge...The mosque committees focus on trivialities and irrelevant arguments that have no place in our time. (Ham)

Despite the mosque's efforts in this context, participants were reluctant to confirm the contribution of ME towards preparing them for life in a British society (Ahmed, 2012; Meer, 2009). Living in a multifaith and multicultural society presents challenges to YBMs. Two of the participants made it clear that mosque education has very little impact on them in terms of preparing them to live in society as British Muslims. One said: “...the mosque education did not prepare me for life as a British Muslim in the real world" (Ham). A second added: "...Possibly, maybe it took up time which could have been used to integrate with non-Muslims, which would have made integration into Western society much easier as a teenager" (Moh). Further, they raised concerns to be addressed by the mosque management in order to fulfil their duties towards YBMs. One participant 
said: "...the mosque should prepare (youth) to live in the world as a practising Muslim despite all the challenges involved and prepare them to contribute to it, prepare them in how to interact with Muslims and non-Muslims socially and professionally (Ham).

\section{Mental Development}

The interviews also stressed that mental and cognitive development were important reasons why YBMs were attending mosque education during their childhood. According to the participants, mosque education contributed positively to their mental and cognitive development through different types of learning that helped them to reach where they are today (Berglund \& Gent, 2019; Gent, 2011; Tamuri et al., 2012). They also highlighted several advantages of attending ME. For example, one participant stated: “The [mosque] education was very useful in providing me with a basis in Islam and providing me with an opportunity to memorise the Quran. This has been incredibly helpful in my life" (Ham).

This was consistent among participants in this research. Further, some of them believed that the mosque should be at the heart of Islamic education in the West as it can play an important role in their lives. One participant stated: "Masjid education as a whole has had a very positive impact on me, alhamdulillah. As a young child, I attended madrasah. This allowed me to learn my masnoon duas for daily life, develop an understanding of the Arabic language" (Saj).

On another level, mosque education offers YBM professionals an opportunity to further educate themselves about Islamic topics, including those that are necessary for their personal development. According to these informants, it helped young individuals to develop their professional skills, such as communication skills, teamwork, planning events, etc. One participant stated:

My most recent mosque education ...was where I attend a weekly class covering; Figh, Tafseer, Aqidah, Seerah studies. As a young professional, this weekend class allows me to continue with my Islamic development and has given me an understanding of aspects of the religion that I may have overlooked as a young boy... being involved in the masjid in a voluntary capacity has allowed me to develop skills that I use in my professional life. For example, good communication skills, leading and planning events, dinners, working in a team, and giving ideas in different community projects. (Saj)

The data from the five key informants suggested that limitations and challenges are facing $\mathrm{ME}$, which in turn hinders its contribution to $\mathrm{YBMs}^{\prime}$ mental and cognitive development. These are issues related to teachers, imams, and pedagogies.

Teachers who are in charge of the teaching and learning process in the mosque are seen in two different ways (Pels, 2014). Some participants viewed teachers as amazing and good teachers who helped students achieve success in life. One participant said: "Yes, due to having good teachers, these teachers are now rare" (Msi). Another added: "... I met many amazing teachers who served as role models for me in a physical sense..." (Saj). 
Some other participants claimed that mosque education is facing many challenges, one of which concerns current teachers and imams (Khan et al., 2005; Lewis, 2002; Sieckelink et al., 2012; and Zözeri et al., 2017). Criticisms directed at teachers took three forms: first, not being friendly with students during lesson time, which caused some students to be reluctant to continue going to the mosque. One participant stated: "... [because of the teacher], I disliked going to madrasah and my Qur'an studies only improved from the age of 10 onwards (very late) when we had a personal Qur' an tutor in the home environment" (Saj). Second was the issue of unqualified teachers being responsible for educating young minds in the mosque, and their educational abilities to respond intellectually to related contemporary life issues. One participant stated: "The lack of qualified teachers, most teachers do not have a university education and have no idea how to respond intelligently to questions about life in the $21^{\text {st }}$ century" (Ham). Thirdly was the issue of foreign-born teachers, and the gaps in their knowledge concerning students born and raised in the UK, and the relevance of teachers' experience to the student's reality. One participant said:

I think the biggest challenge is the fact that the teachers at the mosque were from abroad and their students were UK born and raised. It was difficult for them to relate to us as children and so the culture within lessons very much became a "hear and obey" culture - the teacher tells us to memorise, so we memorise and don't question. (Moh).

Imams are similar to teachers in that they do teach in the mosque. Therefore, the above criticism is true. However, the negative impact of these criticisms was hypothetically larger in the case of imams as they are in charge of other services in the mosque, and in that, they have more religious authority in the eyes of the community. Among the criticisms directed at imams, in the context of teaching YBMs, was that of ignoring current and contemporary religious content related to YBMs, when teaching about Islamic studies. The negative impact of this problem increases when YBMs start talking about it as an obstacle to their religious education. One participant said:

There are many challenges that we need to tackle. The first is probably the fact that our Imams, trustees, and main people involved with the masjid are not born and raised in this country. Naturally, they are therefore at a disadvantage when it comes to trying to understand the problems and issues facing the youth today in the socio-political climate that we find ourselves in. (Saj)

According to participants, training is a key factor in changing the status quo of mosque education. There should be training for all those involved in the mosque education and on several issues, such as teaching strategies and ways in which to offer support and counselling for students, parents, and anyone who attends the mosque activities. One participant said: “... offering training to Imams, training for counselling and mentoring, pedagogy but with a caveat. Training for committee members and trustees, the Imam, committee, and all stakeholders wanting and supporting the same targets" (Zai).

Knowing pedagogy, or how to teach, is an important factor to achieve effective teaching and learning. Participants identified some important areas related to 
pedagogy in mosque education. The teaching and learning environment inside the mosques is sometimes limited and there is no chance to discuss some issues freely and openly. Participants confirmed that there are issues that students cannot ask or enquire about. One participant said: "... some of these include the generation gap and the shame involved in discussing seemingly taboo topics in the masjid setting" (Saj). Failing to address these issues could, according to participants, lead to further damage in the personalities of YBMs. One participant stated: "This leads to some YBMs becoming isolated, cut off and unable to voice their inner challenges. This could lead to further stigma and possibly more drastic consequences for the individual and community as a whole" (Saj).

The lack of experience in classroom management strategies among teachers leads students to undergo some unpleasant experiences during their learning journey in the mosque. It is confirmed that these discipline measures have hindered some students' progress. One participant said:

It is here where I realized that if I fell behind a little, I would be punished with different types of disciplinary measures, including standing outside the classroom, or in another isolated area... I felt picked on, isolated and my progress was further hindered. (Saj)

\section{Spiritual Development}

The findings confirm that mosque education has an important input to the tarbiyah or spiritual development of YBMs. Since the main content of ME is studying and memorising the holy book of Qur'an, then the link with spirituality is strong as the holy Qur'an is the book of tarbiyah and spirituality, according to Muslim belief.

Participants believe that Mosque education has an important role to play in supplementing the work of the Muslim family in developing their children's identity spiritually by attaching the children to the Qur' an and sunnah. One participant said: "... [it] provides spiritual foundations" (Zai). Another added: "I think the mosque is there to supplement the Islamic tarbiyah of parents. It keeps children busy whilst they are young and keeps their hearts attached to the Qur'an and the sunnah of the Prophet (saw)" (Moh).

Other participants argued that this issue is very important and that mosque committees should plan more learning activities that are relevant to achieving a good level of Tarbiyah and spiritual development among YBMs. They suggested the mosque committees organize courses during school holidays to maintain strong spiritual connections among the mosque attendees. One participant said:

From a spiritual development perspective, it is vital that the masjid offers regular courses and workshops to maintain a strong spiritual connection amongst the congregation. I believe this is especially important for our children and such programs and courses should be run in synchrony during school holidays (Easter, half term, Ramadan, Summer, and Christmas) to provide an alternative form of entertainment for our YBM. (Saj)

One of the main roles of the mosque is to give YBMs a space to engage in different religious duties and perform daily prayers. This important role has its implications on developing the spiritual character of Muslims. One participant 
said: "The roles of the mosque for Young British Muslims are multiple, including of course providing a prayer space... for older adults, the masjid is a place for their worship and staying in touch with the community" (Saj).

The participants identified another role for the mosque which has its spiritual impact over the YBM, and that is counselling. This is important as many people do not find the courage or the needed support from the family to visit counsellors due to cultural taboos. Further, the mosque could be the first station in identifying those who need help or those who need a clinical referral. One participant said: "...counselling is a first choice point of reference" (Zai). Another added: "...with the rise of mental health problems in the UK and amongst the Muslim community, ensuring that families are well-supported and receive the relevant counselling is also critical" (Saj).

Developing the YBMs personality is yet another added benefit to attending ME, according to the participants, who said that mosque education had contributed to the development of their personalities. They felt that it had helped them in building their emotional, psychological, and mental capacities. One participant highlighted that mosque education had helped him in many ways:

It helped in creating a mindset that helps in processing moments and happenings whether personal or global, in a positive light... it made me demarcate safety perimeters around me... I read today and love books only because of my initial positive introduction to reading which took place in the mosque setting. (Zai)

\section{Recommendations}

It is evident that mosque education has a weighty impact on the educational, social, and spiritual aspects of the lives of young British Muslims. However, there are important areas that require more attention from different stakeholders to maintain a good relationship between the mosque and society at large. I put forward the following recommendations to policymakers, Muslim community leaders, mosque committee members, Imams, Muslim educationalists, researchers, and research centres: First, there is a need to review and evaluate the content of the delivered Islamic knowledge to YBMs, or at least to develop general guidelines and a framework to organize the religious content imparted to YBMs. It is recommended that these guidelines be sensitive to pluralism and diversity. Second, it is suggested to have an agenda for capacity-building initiatives for people working within these institutions. Empowering teachers, Imams, and administration teams in mosques through training programs and professional development workshops contribute to better outcomes and help overcome the many criticisms directed at mosque education. Third, the mosque has a strong spiritual impact over YBMs, yet there is no effort made to deeply investigate the relationship between spirituality and being a well-informed Muslim citizen in a multicultural society. Fourth, it is believed that research centres and research students have plenty of scope for their work as there are many areas which require further exploration and more focused research projects to reflect the importance of integrating the YBM into the wider society. Fifth, the society at large, as well as the Muslim minority, will benefit from any further efforts geared towards bringing youth together, Muslims and non-Muslims, religious and secular, practicing and non-practicing. Therefore, the research 
centres are encouraged to explore this area and prompt appropriate research to better understand how to help YBMs navigate the challenges that face them.

\section{References}

Abdel-Hady, Z. (2010). The masjid, yesterday and today. The Center for International and Regional Studies. Georgetown University School of Foreign Service in Qatar.

Abu Daf, M. (2007). Introduction to Islamic education. Gaza: Aafaaq Library.

Adam-Bagley, C., \& Abubaker, M. (2019). "Islamic ethics, sociology and social justice - A Critical Realist perspective and a feminist viewpoint". In C. Adam-Bagley \& M. Abubaker (Eds.), Muslim Women Seeking Power, Muslim Youth Seeking Justice: Studies from Europe, Middle East and Asia. Newcastle: Cambridge Scholars Publishing.

Ahmed, F. (2012). Tarbiyah for shakhsiyah (educating for identity): seeking out culturally coherent pedagogy for Muslim children in Britain. Compare: A Journal of Comparative and International Education, 42(5), 725-749. https:// doi.org/10.1080/03057925.2012.706452.

Al-Ghazali, M. (2018). Understanding the life of Prophet Muhammad. CreateSpace Independent Publishing Platform.

Al-Hashimy, A. T. (2006). Methods of teaching Islamic education skills. Beirut: Al-Resalah Publishers.

Al-Refai, N., \& Bagley, C. (2008). Citizenship education: The British Muslim perspective. Rotterdam: Sense Publishers. https://doi.org/10.1163/9789087906337

Alsaawi, A. A. (2017). Imams' language use in mosque sermons (Ph.D. thesis). Newcastle University.

An-Nawawi. (2014). The forty hadith. In E. Ibrahim \& D. Davies (Eds.), Translators. Createspace Independent Publishers.

Attride-Stirling, J. (2001). Thematic networks: An analytic tool for qualitative research Qualitative Research, 1(3), 385-405. https://doi.org/10.1177/146879410100100307

Berger, M. (2014). “The Netherlands". In J. Cesari (Ed.), Oxford handbook of European Islam (pp. 1-83). https://doi.org/10.1093/oxfordhb/9780199607976.013.5

Berglund, J., \& Gent, B. (2019). Qur'anic education and non-confessional RE: An intercultural perspective. Intercultural Education, 30(3), 323-334. https:// doi.org/10.1080/14675986.2018.1539305

Bhuiyan, H. A. (2010). Ethnography of identity, assimilation, and the dynamics of community relationship: The study of Muslims in the Utah Salt Lake Valley area (Ph.D. Thesis). The University of Utah.

Cherti, M., \& Bradley, L. (2011). Inside madrasas: Understanding and engaging with BritishMuslim faith supplementary schools. London: Institute for Public Policy Research. https:// doi.org/10.1080/01416200.2012.707844

Cholil, M. (2016). Revitalization of mosque role and function through development of "Posdaya" in the view of structuration theory. Research on Humanities and Social Sciences, 6(12), 43-51.

Crowe, S., Cresswell, K., Robertson, A., Huby, G., Avery, A., \& Sheikh, A. (2011). The case study approach. BMC Medical Research Methodology, 11(1), 100. https://doi.org/10.1186/1471-2288-11-100

Gent, B. (2011). The world of the British hifz class student: Observations, findings, and implications for education and further research. British Journal of Religious Education, 33(1), 3-15. https://doi.org/10.1080/01416200.2011.523516 
Halder, A. (2013). Pedagogy and discipline in madrasas. Munich: GRIN Verlag. Retrieved from http://www.grin.com/en/e-book/295333/pedagogy-and-discipline-inmadrasas

Halstead, J. M. (2004). An Islamic concept of education. Comparative Education, 40(4). https:/ / doi.org/10.1080/0305006042000284510

Husain, E. (2018). The house of Islam: A global history. London: Bloomsbury Publishing.

Ibn Majah, M. (2007). Sunan Ibn Majah [The hadith collection by Ibn Majah]. Translated by: N. Al-Khattab. Saudi Arabia: Darussalam.

Ikhwan, A., \& Jaelani, D. I. (2014). Introduction to the Islamic education concepts (an integral paradigm building efforts). In International Seminar on Islamic Law, Economic, Education and Science (p. 136). https://doi.org/10.1057/9781137382474_1

Khan, S., Husain, W., \& Masood, S. (2005). Situating weekend Islamic schools in the American Muslim context. Paper delivered at the ISNA Education Forum, March (Vol. 10).

Lewis, P. (2002). "Between Lord Ahmed and Ali G: Which future for British Muslims?". In W. A. R. Shadid \& P. S. van Koningsveld (Eds.), Religious freedom and the neutrality of the state: The position of Islam in the European Union, (pp. 129-144). Leuven: Peeters.

Maylor, U., Glass, K., Issa, T., Kuyok, K. A., Minty, S., Rose, A., ... Purdon, S. (2010). The impact of supplementary schools on pupils' attainment: An investigation into what factors contribute to educational improvements. Nottingham: Department for Children, Schools, and Families.

Meer, N. (2009). Identity articulations, mobilization, and autonomy in the movement for Muslim schools in Britain. Race Ethnicity and Education, 12(3), 379-399. https:// doi.org/10.1080/13613320903178311

Modood, T. (2013). Multiculturalism: A civic idea. Cambridge: Polity Press.

Moore, L. (2012). Muslim children's other schools. Childhood Education, 88(5), 298-303. https://doi.org/10.1080/00094056.2012.718243

Mortada, M. (2003). Traditional Islamic principles of built environment. London: Routledge Curzon. https:/ / doi.org/10.4324/9780203422687

Moutselos, M. (2019). Praying on Friday, voting on Sunday? Mosque attendance and voter turnout in three West European democracies. Journal of Ethnic and Migration Studies, 46(11), 2275-2292. https:/ / doi.org/10.1080/1369183x.2019.1662283

Naqshbandi, M. (2017). UK mosque statistics: Masjid statistics. Derived from data listed in the Mosques. Retrieved from www.MuslimsInBritain.org

Pels, T. (2014). "Dilemmas of educating Muslim children in the Dutch immigration context". In M. Sedgwick (Ed.) Making European Muslims: Religious socialization among young Muslims in Scandinavia and Western Europe, (pp. 56-73). New York, NY: Routledge. https:/ / doi.org/10.4324/9781315764894-10

Rajabi-Ardeshiri, M. (2011). Children and conflict: Exploring children's agency at UK mosque schools. International Journal of Children's Rights, 19(4), 691-704. https://doi.org/10.1163/157181810x522306

Rasdi, M. T. M. (2014). Rethinking the mosque in the modern Muslim society. ITBM.

Rosowsky, A. (2013). Faith, phonics, and identity: Reading in faith complementary schools. Literacy, 47(2), 67-78. https://doi.org/10.1111/j.1741-4369.2012.00669.x

Sahin, A. (2013). New directions in Islamic education: Pedagogy and identity formation. Markfield: Kube.

Schuitema, J. A., ten Dam, G., \& Veugelers, W. (2008). Teaching strategies for moral education: A review. Journal of Curriculum Studies, 40(1), 69-89. https://doi.org/10.1080/00220270701294210 
Sözeri, S., Kosar-Altinyelken, H., \&Volman, M. (2017). Mapping discourses on mosque education in the Netherlands: A content analysis of the Dutch press, 2010-2016. Discourse: Studies in the Cultural Politics of Education, 40(3), 358-371. https://doi.org/10.1080/01596306.2017.1316705

Spahic, O. (2009). The history and character of the Islamic built environment. Selangor: Arah Publications.

Tamuri, A. H., Ismail, M. F., \& Jasmi, K. A. (2012). A new approach in Islamic education: Mosque based teaching and learning. Journal of Islamic and Arabic Education, 4(1), 1-10.

Ten Dam, G., \& Volman, M. (2004). Critical thinking as a citizenship competence: teaching $\begin{array}{llll}\text { strategies. Learning and instruction, 14(4), 359-379. } & \text {. }\end{array}$ https://doi.org/10.1016/j.learninstruc.2004.01.005

Tesch, R. (2013). Qualitative research: Analysis types and software. Routledge. https://doi.org/10.4324/9781315067339

Triayudha, A., Pramitasary, R. N., Anas, H. A., \& Mahfud, C. (2019). Relations between mosque and social history of Islamic education. HUNAFA: JurnalStudiaIslamika, 16(1), 142-153. https:// doi.org/10.24239/jsi.v16i1.531.142-153

Zaimeche, S. (2002). Education in Islam: The role of the mosque. United Kingdom: Foundation for Science Technology and Civilization.

Zaman, M., \& Memon, N. A. (Eds.). (2016). Philosophies of Islamic education: Historical perspectives and emerging discourses. Routledge.

https://doi.org/10.4324/9781315765501 